\title{
Ecologists fear Antarctic krill crisis
}

The humble Antarctic krill (Euphausia superba) bears a heavy burden. It may be just a small, shrimp-like crustacean, but its sheer abundance makes it one of the largest protein sources on Earth, eagerly sought by fish, penguins, whales - and man.

Ecologists are now warning that the rapid growth in krill fishing is adding to the pressure of environmental changes threatening the creatures, and are calling for better monitoring and precautionary management of krill fisheries.

The global fish-farming industry is increasingly relying on krill-based fish feed, and enzymes and chemicals derived from krill are included in a number of dietary and medical products. Last year, for example, Aker Biomarine, an Oslo-based company specializing in harvesting and processing Antarctic krill in the Southern Ocean, upgraded its krill harvesting vessel, the Saga Sea, to boost its catch. In the first half of 2010 it produced 8,600 tonnes of krill meal for the aquaculture market, up from 6,200 tonnes during the whole 2009 catch season. The total krill catch this season is expected to be 150,000-180,000 tonnes, exceeding last year's total by about $40 \%$.

In May, Aker Biomarine's krill fishing was certified by the Marine Stewardship Council (MSC), a London-based organization that aims to promote sustainable fishing practices by allowing catch from MSCcertified fisheries to be labelled as such (see 'Grabbing a bite'). The Pew Environment

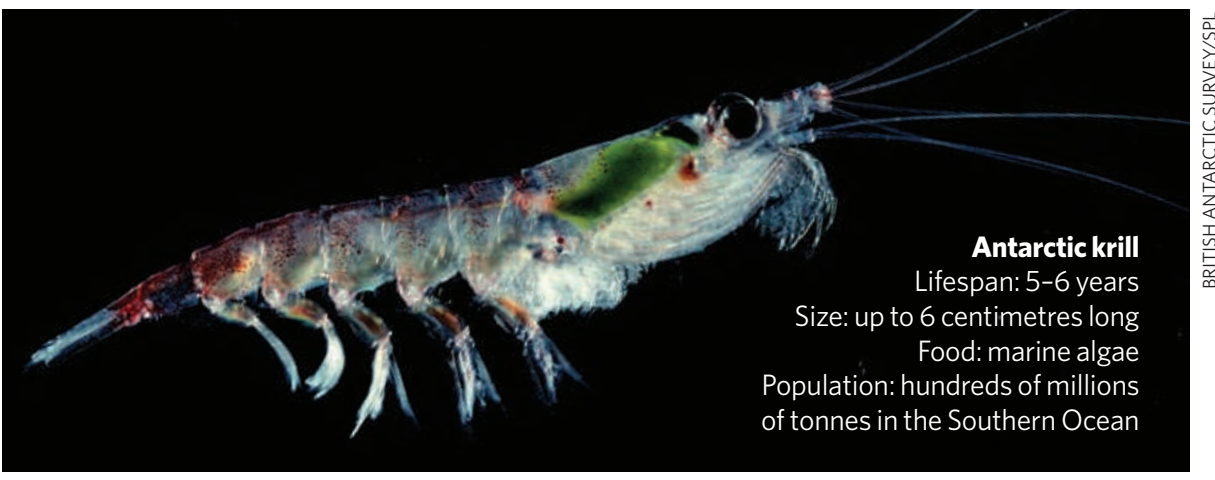

Group, an environmental advocacy group based in Washington DC, has objected to this, arguing that fishing for fishmeal should not be eligible for MSC certification. The row will come to a head at the October meeting of the Convention for the Conservation of Antarctic Marine Living Resources (CCAMLR), an international body responsible for managing the fisheries in the Southern Ocean.

One issue for debate will be the CCAMLR's annual catch limit of 3.47 million tonnes in the Atlantic-bordering section of the Southern Ocean, the main fishing ground for Antarctic krill. "Current krill management fails to take account of the subtleties of the ecosystem," says Volker Siegel, a marine biologist at the Institute for Sea Fisheries in Hamburg, Germany, and member of the European Union's CCAMLR delegation. Siegel says that rather than setting an oceanwide limit, krill fisheries should be regulated

\section{Grabbing a bite}

Fishing for the Antarctic toothfish (Dissostichus mawsoni) could soon be declared sustainable by the Marine Stewardship Council (MSC), drawing ire from scientists who say that the certification will put pressure on a vulnerable species. In 2007, three fishing companies asked the MSC to assess the toothfish fishery in the Ross Sea off Antarctica, so that their catch could carry the desirable tag of 'sustainable'. A report prepared for the council by Moody Marine, a fisheries assessment company in Derby, UK, strongly supports the certification. And Mark Belchier, a marine researcher with the British Antarctic Survey and part of the UK delegation to the Convention for the Conservation of Antarctic Marine Living Resources, which determines Antarctic catch levels, agrees that the fishery could be sustainable.

But the Antarctic and Southern Ocean Coalition (ASOC), an environmental group in Washington DC, is protesting the assessment, as it did when the MSC certified krill. "There are profound lacks of knowledge of how the toothfish population works," says James Barnes, executive director of ASOC. The toothfish, often sold as Chilean sea bass, is slowgrowing and can take a decade to reach sexual maturity, so the population could be harmed easily by the increased demand that 'sustainable' branding brings, says Barnes. The MSC's independent lawyer Michael Lodge, based in Kingston, Jamaica, is now weighing the merits of the objection, and will make a decision after the 2 September deadline for stakeholder consultation. Daniel Cressey on a smaller scale, because much of the fishing is limited to a few sites.

Another worry is the number of fishing vessels being deployed in the Southern Ocean. Norway is now operating three ships, for example, and China is expected to rapidly increase its krill fishing after sending its first vessel this year. "If China starts fishing in a big way, catch will expand rapidly, outstripping our ability to orderly manage it," says Steve Nicol, a marine ecologist with the Australian Antarctic Division in Kingston, Tasmania, who advises the Australian government on krill fisheries.

Researchers suspect that Antarctic krill are also feeling the effect of climate change. Krill larvae feed on algae living on the bottom of sea ice, which is rapidly dwindling around the Antarctic Peninsula. According to one estimate, the number of krill in the Southern Ocean may have dropped by $80 \%$ since the 1970 s. But "there is no definite answer as to how the krill responds to warming", says Nicol. It is also unclear whether krill stocks are transient or fixed to given areas, and how many live deeper than 200 metres, below the most heavily fished and studied region of the ocean.

Mandatory scientific observers on board all krill fishing vessels - as is common practice in all other Antarctic fisheries could help to answer these questions, Nicol says. Scientists are welcome on board the Saga Sea, but Japanese and North Korean ship owners are resistant to the idea. While there is still so much uncertainty about krill populations, "we must not allow the fishery to expand too quickly", says Nicol. "We don't want to get in a situation where we have to tell people to get their boats out because we allowed them to catch too much, as has happened in other fisheries."

Quirin Schiermeier

See Opinion, page 28. 


\section{'Climate wars' claims disputed}

The idea that climate change might be a trigger for social disorder, population migration and conflict has an impressive pedigree. The link was mooted in a 2003 report for the Pentagon on the nationalsecurity implications of climate change; by the Stern review on the economics of climate change, prepared for the UK government in 2006; and in the United Nations' post-conflict environmental assessment of Sudan in 2007, which suggested that climate change was an aggravating factor in the Darfur conflict.

But is there real proof of a link between climate change and civil war?

No, says Halvard Buhaug, a political scientist with the Peace Research Institute Oslo. In research published this week ${ }^{1}$, he finds almost no correlation between climatechange indicators, such as temperature and rainfall variability, and the frequency of civil wars over the past 50 years in subSaharan Africa - arguably the part of the world that is socially and environmentally most vulnerable to climate change. "The primary causes of civil war are political, not environmental," says Buhaug.

The analysis challenges a study published last year by Marshall Burke, an economist at the University of California, Berkeley, and colleagues, who reported a strong historical relationship between temperature and the incidence of civil war ${ }^{2}$. They found that the likelihood of armed conflict across the continent rose by some $50 \%$ in unusually warm years between 1981 and 2002.

Neither Burke nor Buhaug is giving any ground; each challenges the other's definition of 'civil war' and choice of climate data sets.

Given the many causes of unrest, it is not surprising that a meaningful correlation with climate is hard to pin down, says Hans Joachim Schellnhuber, director of the Potsdam Institute for
Climate Impact Research in Germany.

"This does not at all diminish the

importance of responding to climate change," adds Roger Pielke, a climate policy expert at the University of Colorado in Boulder. "But it does offer a stark warning about trying to use overly simplistic notions of cause and effect to advocate for such actions."

Quirin Schiermeier

1. Buhaug, H. Proc. Natl Acad. Sci. USA doi:10.1073/ pnas.1005739107 (2010).

2. Burke, M. B. et al. Proc. Natl Acad. Sci. USA 106, 20670-20674 (2009)

See go.nature.com/gcUcl4 for a longer version of this story.

\section{Correction}

The article 'Ecologists fear Antarctic krill crisis' (Nature 467, 15; 2010) incorrectly stated that North Korean ship owners are resistant to the idea of granting scientists access to commercial fishing vessels. It should have said 'South Korean'. 